\title{
PENERAPAN METODE GALLERY WALK PADA PELATIHAN APLIKASI SLEEKR ACCOUNTING BAGI KOPERASI DI KOTA BENGKULU
}

\section{GALLERY WORK METHOD ON TRAINING OF THE SLEEKR ACCOUNTING APPLICATION FOR COOPERATIVES IN BENGKULU CITY}

\author{
Oleh: \\ Siti Aisyah, Nila Aprilla, Fenny Marietza \\ Fakultas Ekonomi dan Bisnis, Universitas Bengkulu \\ Email: sitiaisyah@unib.ac.id
}

\begin{abstract}
This science-based community service's activity aims to provide additional basic knowledge of cooperative accounting in order to assist SMEs accounting manager or staff in applying Sleekr Accounting through training and assistance for partners of cooperatives in the City of Bengkulu. The training was held for 2 days and attended by 16 partner cooperatives through the Bengkulu City Cooperatives and SMEs Office. Cooperative accounting training is carried out using the Gallery Walk active training method. This method is very useful for exploring participants' knowledge and making participants more active and focused on activities. From this training, participants were able to compile a standard account chart with in their group. Training in the use of sleekr accounting applications is delivered using a mixed method between lectures, discussions, and practices. From this training, participants can set-up early by using standard account chart data that they have compiled in the first day training.
\end{abstract}

Keywords: Cloud Accounting, Cooperatives, gallery walk

\section{PENDAHULUAN}

Pertumbuhan jumlah dan kualitas usaha koperasi lebih lamban jika dibandingkan dengan UKM yang ada di kota Bengkulu. Hal ini disebabkan karena koperasi tidak dapat beroperasi seadanya. Koperasi harus memenuhi ketentuan hukum yang berkaitan dengan peraturan pendirian dan pengoperasion koperasi di banding UKM. Pada Tahun 2017, di Kota Bengkulu terdapat 888 koperasi. Dari total angka tersebut, banyak koperasi yang tidak beroperasi lagi karena tidak mematuhi peraturan mengenai koperasi.

Berdasarkan surat Kementerian Koperasi dan UMKM RI, No. 244/Dep.1/XII/2016, tahun 2017 yang lalu, terdapat 58 koperasi yang berada di Kota Bengkulu dibubarkan karena tidak pernah melaksanakan rapat tahunan dan tidak menjalankan prinsip-prinsip koperasi. Per Maret tahun 2018, berdasarkan data dari www.nik.depkop.go.id, saat ini terdapat 758 koperasi di Kota Bengkulu yang terdaftar di kementerian dengan status aktif tetapi ada yang memiliki sertifikat, ada pula yang belum memiliki sertifikat.

Dalam operasionalnya, koperasi harus dikelola secara profesional sehingga pengelolaannya harus mengandung prinsip keterbukaan, transparansi, dan akuntabel 
melalui penyelenggaraaan catatan yang benar sesuai dengan standar akuntansi yang telah ditetapkan oleh Dewan Standar Akuntansi Keuangan dari Ikatan Akuntan Indonesia dalam Standar Akuntansi Keuangan Entitas Tanpa Akuntabilitas Publik (SAK ETAP). Pada akhir tahun atau periode yang ditentukan, pengelola koperasi harus mempertanggungjawabkan laporan keuangan koperasi melalui Rapat Anggota Tahunan (RAT). Pada saat itu RAT, juga ditentukan besaran Sisa Hasil Usaha (SHU) yang akan dibagikan kepada anggota.

Pencatatan dana dari anggota dan layanan lainnya harus dilakukan secara detail dan teliti (akurat). Hal ini kadang kala kurang menjadi perhatian para pengelola. Banyak faktor yang menyebabkan hal ini, seperti kurangnya pengetahuan mengenai akuntansi sehingga laporan yang dibuat kurang lengkap.

Dengan semakin kompleksnya bisnis koperasi, mulai dari bertambahnya anggota dan layanannya, penyusunan laporan keuangan yang dipersyaratkan oleh SAK ETAP menjadi lebih kompleks. Penyusunan laporan harus dilakukan oleh petugas atau orang yang memiliki kemampuan dan keahlian di bidang pelaporan keuangan yaitu akuntansi.

Di satu sisi, penyusunan laporan terkendala oleh lambannya penyusunan laporan keuangan karena masih menggunakan pencatatan akuntansi sampai dengan penyusunan secara manual (pena dan kertas saja, atau berbantukan aplikasi excel yang belum menggunakan macro). Padahal, saat ini banyak tersedia aplikasi yang memudahkan penyusun laporan keuangan koperasi.

Aplikasi akuntansi berbasis cloud computing hanya merupakan alat bantu dalam mempercepat penyusunan laporan keuangan karena tidak ada redundancy data (pencatatan berulang kali). Aplikasi-aplikasi yang tersedia banyak yang mendukung (support) koperasi karena mudah, murah, dan sederhana.

Pada dasarnya, tidak banyak yang berubah dalam produk perangkat lunak (aplikasi) akuntansi yang digunakan oleh para pengguna untuk menghasilkan laporan keuangan saat ini jika dibandingkan dengan beberapa dekade yang lalu. Perbedaan yang sangat signifikan adalah platform aplikasi tersebut.

Aplikasi akuntansi sebelum munculnya aplikasi berflatform cloud computing (Williams, 2010) mengharuskan pengguna untuk menginstall aplikasi ke dalam komputer yang hanya bekerja pada satu komputer saja dan hanya dapat diakses oleh satu user saja. Pihak kunci (key person) tidak dapat secara langsung mengakses detail keuangan dan pelanggan. Dari sisi data, data dipindah dari satu media ke media lain, sebagai contoh dipindah ke sebuah USB drive. Data yang terdapat di dalam sistem tidak bisa update. Pemeliharaan atau back sangat mahal dan rumit. Dengan demikian, hal ini sangat tidak aman dan tidak dapat diandalkan. Dari sisi software, cukup sulit diperbaharui (update) dan mahal. Kadang kala hardware tidak dapat memenuhi spesifikasi software yang diperbaharui.

Dalam cloud computing, pengguna mengakses aplikasi software secara terpisah melalui internet atau jaringan lainnya via sebuah service provider aplikasi cloud (Hugos dan Hulitzk, 2011) . Penggunaan software akuntansi berbasis cloud membebaskan bisnis dari keharusan untuk menginstal dan memelihara software pada computer personal. Hal ini memungkinkan karyawan di bagian lain, kantor cabang untuk mengakses data yang sama dengan software dengan versi yang sama.

Sleekr Accounting adalah aplikasi akuntansi karya asli dari ahli teknologi sistem informasi akuntansi Indonesia. Sleekr Accounting merupakan platform bisnis yang didesain untuk UKM Indonesia. Perancang aplikasi ini percaya bahwa usaha kecil dan menengah di Indonesia memiliki peluang bertumbuh yang sangat besar jika didukung dengan teknologi terdepan dan manajemen sumber daya yang efektif dan efisien. 
Sleekr Accounting adalah software akuntansi berbasis cloud accounting yang membantu pemilik bisnis memiliki informasi real-time untuk posisi keuangan perusahaan. Berbagai jenis perusahaan telah menggunakan aplikasi Sleekr Accounting, mulai dari strart-up sampai dengan perusahaan besar. Walaupun demikian, biaya langganan aplikasi ini terjangkau untuk UKM di Indonesia. Jasa ini ditawarkan mulai Rp 145.000,00 per bulan.

Masalah yang dihadapi oleh mitra adalah: 1). mitra belum atau kurang memiliki pengetahuan di bidang ilmu akuntansi sebagai dasar keahlian untuk mencatat transaksi; lebih banyak pengelola koperasi melakukan pencatatan transaksi koperasi mereka dalam bentuk uang kas masuk dan keluar, catatan uang iuran anggota dan pinjaman anggota. Catatan ini masih dilakukan secara sederhana; 2). mitra kurang memiliki pengetahuan tentang pemanfaatan aplikasi akuntansi yang ada di dalam perangkat IT yang mereka miliki. Kalaupun berbantukan komputer, mereka masih menggunakan aplikasi office excell yang belum menggunakan formula yang otomatis. Dengan demikian, pekerjaan administrasi keuangan menjadi lambat dan sulit dengan cepat menghasilkan informasi Saat ini, aplikasi akuntansi hanya sejangkauan tangan saja, aplikasi itu dapat dimanfaatkan dengan mudah dengan peralatan teknologi yang biasa kita gunakan (laptop, telepon genggam, dll); 3). tidak memiliki sumber daya manusia memiliki kompetensi di bidang akuntansi dan alat bantu dengan pemanfaatan teknologi. Pengelola koperasi biasanya diinisiasi oleh pengelola pendiri koperasi dengan menunjuk orang-orang yang berada dalam koperasi. Hal ini kadang kala tidak didukung oleh adanya pengelola dan anggota yang memiliki kompetensi di bidang akuntansi dan aplikasi akuntansi; 4). mitra tidak memiliki pendamping yang handal dalam pemanfaatan sistem informasi akuntansi karena tidak ada yang mensupervisi secara benar; Keengganan pengelola koperasi dalam pemanfaatan teknologi aplikasi akuntansi adalah ketidakyakinan akan catatan yang dilakukan dan pemilihan aplikasi yang terjangkau (murah) dan user user friendly jika tidak ada pihak lain yang dapat menyatakan atau melakukan review atau evaluasi atas penerapan aplikasi akuntansi yang mereka lakukan.

Dengan adanya aplikasi Sleekr Accounting yang dapat diterapkan oleh pengelola koperasi, maka secara rinci tujuan kegiatan ini adalah sebagai berikut: 1). memberikan tambahan pengetahuan dasar akuntansi untuk dapat membantu mereka dalam menggunakan Sleekr Accounting; 2). memberikan tambahan pengetahuan dan keterampilan mengenai cara penggunaan aplikasi Sleekr Accounting; 3). membantu pengelola koperasi untuk menerapkan aplikasi Sleekr Accounting secara berkelanjutan melalui pendampingan; 4). mewujudkan sebuah pusat pelatihan dan jasa konsultasi akuntansi bagi koperasi dan UKM di Kota Bengkulu.

\section{METODE PENGABDIAN}

Kegiatan PPM berbasis ipteks dilaksanakan pada tanggal 6-7 Agustus 2018 bertempat di ruang serba guna Dinas Koperasi dan UKM Kota Bengkulu dengan mengundang 20 koperasi. Khalayak sasaran kegiatan ini adalah mitra yang terdaftar pada Dinas Koperasi dan UMKM Kota Bengkulu. Jumlah koperasi yang dipilih untuk mengikuti kegiatan ini adalah sebanyak 20 koperasi. Kegiatan ini bekerja sama dengan Dinas Koperasi dan UKM Kota Bengkulu. Dinas Koperasi dan UKM Kota Bengkulu 
berkontribusi dalam bentuk penyediaan data dan informasi terkait koperasi yang akan menjadi khalayak sasaran kegiatan ini dan menjadi pusat pelatihan dan jasa konsultasi akuntansi bagi koperasi dan UKM di Kota Bengkulu.

Metode untuk kegiatan disesuaikan dengan karakteristik kegiatan. Pada kegiatan pelatihan aplikasi Sleekr Accounting, peserta mengikuti pelatihan sesuai dengan pelatihan yang dirancang oleh pelaksana kegiatan pengabdian. Peserta kegiatan diperkenalkan mengenai aplikasi, manfaat untuk koperasi mereka, dan bagaimana menggunakannya dengan menggunakan soal yang telah disiapkan. Kegiatan pelatihan ini dibagi dalam dua kegiatan yaitu:

a. Pelatihan dasar akuntansi bagi mitra; Metode yang digunakan adalah metode pelatihan/pembelajaran aktif (USAID_HELM, 2015) dengan teknik Pameran Berjalan (Gallery Walk); dengan teknik ini peserta memperkenalkan hasil karya kepada peserta lain dengan cara menempelkan hasil kerja ke dinding. Peserta lain diminta untuk berkunjung ke dinding kerja peserta lain searah jarum jam. Ketika melakukan kunjungan, peserta bertanya dan berdiskusi dengan perwakilan peserta yang ada di tiap dinding kerja, lalu menuliskan saran di selembar kertas kosong lalu menempelkannya di dinding yang dikunjungi.

b. Pelatihan aplikasi Sleekr Accounting; Metode yang digunakan adalah metode campuran yaitu metode campuran ceramah, diskusi, dan praktik. Pelaksana kegiatan dikenalkan dengan aplikasi akuntansi dengan soal yang telah disiapkan oleh pelaksana kegiatan. Soal dirancang khusus untuk usaha koperasi sehingga setelah pelatihan mereka dapat melanjutkan penggunaan aplikasi untuk operasional keuangan koperasi mereka masingmasing.

Dari hasil observasi dan wawancara yang dilakukan, jika ada permasalahan yang dapat diatasi segera oleh pelaksana kegiatan pengabdian, maka pelaksana akan segera memberikan solusi pemecahannya pada saat itu juga. Namun, untuk masalah-masalah yang tidak teridentifikasi pemecahannya pada saat observasi, pelaksana akan mendiskusikan terlebih dahulu di dalam tim pelaksana untuk dicarikan jalan keluar permasalahan. Dari keseluruhan hasil observasi dan wawancara kepada mitra, maka akan didapatkan variabel apa saja yang menjadi variabel yang mendorong dan menghambat penggunaan teknologi informasi terutama teknologi aplikasi akuntansi pada UKM di Kota Bengkulu khususnya koperasi.

Untuk menjamin keberlangsungan kegiatan ini dimasa depan, maka pelaksana mendorong mitra untuk membentuk grup yang mewadahi diskusi para mitra dan Dinas Koperasi dan UKM terkait terutama Seksi Kelembagaan Koperasi. Grup diskusi dapat memanfaatkan teknologi yang sudah dikenal dan biasa digunakan yaitu whatapps. Selain itu, Dinas Koperasi dan UKM Kota Bengkulu didorong untuk membentuk pusat pelatihan dan jasa konsultasi akuntansi bagi koperasi dan UKM se-Kota Bengkulu yang bekerja sama dengan Universitas Bengkulu. Detail dari metode kegiatan dapat dilihat pada tabel berikut ini.

\section{HASIL DAN PEMBAHASAN}

\section{Profil Peserta Kegiatan}

Kegiatan PPM berbasis ipteks dilaksanakan pada tanggal 6-7 Agustus 2018 bertempat di ruang serba guna Dinas Koperasi dan UKM Kota Bengkulu dengan mengundang 20 koperasi. Namun, 20 koperasi yang diundang berbeda dengan koperasi pada saat pengajuan proposal. Penggantian peserta ini atas saran Kepala Dinas Koperasi dan UKM Kota Bengkulu. Koperasi-koperasi yang menggantikan adalah koperasi-koperasi 
yang dinilai telah cukup maju dan dapat menerima perubahan sistem menuju sistem dengan bantuan teknologi terkini. Kegiatan ini dibuka langsung oleh Kepala Dinas Koperasi dan UKM Kota Bengkulu.

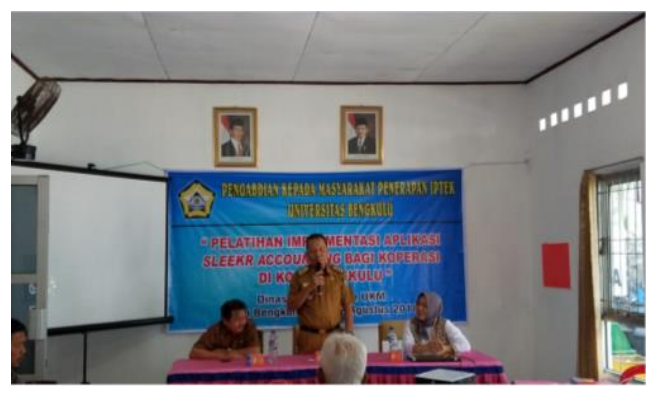

Gambar 1. Pembukaan Kegiatan Pelatihan oleh Ka. Dinas Koperasi dan UKM

Dari 20 koperasi yang diundang, hanya 16 koperasi yang hadir secara penuh selama 2 hari. Hal ini menunjukkan tingkat kehadiran sebesar $80 \%$. Dari pengumpulan data awal pada saat kegiatan, didapatkan profil peserta kegiatan sebagai berikut:

Tabel 2. Profil Peserta Kegiatan

\begin{tabular}{lrc}
\hline Profil & Jumlah & Persentase \\
\hline Jenis Kelamin: & 15 & 94 \\
Perempuan & 1 & 6 \\
Laki-laki & $\mathbf{1 6}$ & $\mathbf{1 0 0}$ \\
\hline Total & & \\
\hline Penggunaan Aplikasi: & 2 & 12,5 \\
Ya & 14 & 87,5 \\
Tidak & $\mathbf{1 6}$ & $\mathbf{1 0 0}$ \\
\hline Total & & \\
Alat Bantu Pencatatan dan LK: & & 12 \\
Buku kas/Tradisional & 3 & 69 \\
Excell & 11 & 19 \\
Aplikasi & 2 & $\mathbf{1 0 0}$ \\
& $\mathbf{1 6}$ & \\
\hline Total & & \\
\hline
\end{tabular}

Dari tabel di atas, peserta didominasi oleh peserta perempuan sebesar 94\%. Koperasi yang menggunakan aplikasi hanya $12,5 \%$ saja dan tidak satupun menggunakan aplikasi akuntansi berbasis cloud. Koperasi tersebut mencatat transaksi keuangan dengan bantuan buku kas secra tradisional sebanyak 12\%, mencatat dengan bantuan Excell sebanyak $69 \%$.

\section{Hasil Pelatihan Akuntansi Koperasi Dengan Metode Gallery Walk}

Kegiatan ini dilaksanakan pada hari pertama pelatihan. Pelaksana kegiatan pengabdian memerankan diri sebagai fasilitator. Hal ini dilakukan agar peserta dapat menggali kemampuan dirinya sendiri dengan bimbingan fasilitator dan bahan-bahan yang telah dipersiapkan.

Metode pelatihan dimodifikasi dengan menambah penjaringan harapan dan tantangan mengikuti pelatihan oleh peserta. Peserta diminta untuk menuliskan harapan dan tantangan mereka dalam mengikuti pelatihan ini. Hal ini bertujuan untuk melihat apakah harapan peserta sesuai dengan tujuan kegiatan dan apa saja yang menjadi hambatan dalam 
mengikuti pelatihan ini. Berikut adalah Gambar kegiatan dalam kegiatan penjaringan harapan dan tantangan.

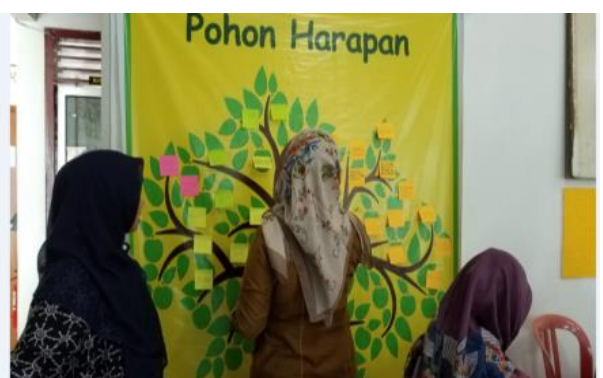

Gambar 2. Peserta Sedang Menempelkan Harapan dan Tantangan pada Pohon Harapan

Pelaksana pengabdian menyusun Modul Pelaksanaan Kegiatan Pengabdian pada Masyarakat Penerapan Ipteks dengan Metode Gallery Walk. Modul pelaksanaan ini disusun dengan tujuan agar seluruh anggota pelaksana dan lapangan dapat bekerja secara efektif.

Seluruh peserta kegiatan diwajibkan untuk mengikuti pre-test dan post-test untuk melihat inkremental pengetahuan sebelum dan sesudah pelatihan. Lembar pre-test dan post-test dapat dilihat dalam modul Pelaksanaan Kegiatan Pengabdian Pada Masyarakat Penerapan Ipteks dengan Metode Gallery Walk. Berikut adalah hasil pre-test dan post test.

Tabel 3. Hasil Pre-test dan Post-test

\begin{tabular}{cclccc}
\hline No & Kelompok & \multicolumn{1}{c}{ Nama } & Pre-test & Post-test & Naik (Turun) \\
\hline 1 & Biru & Nopita Sari & 5,50 & 6,00 & 0,50 \\
2 & Biru & Beni Junaidi & 3,00 & 7,50 & 4,50 \\
3 & Biru & Zapuri & 3,00 & 7,50 & 4,50 \\
4 & Hijau & Fitriyanti BR Sitepu & 4,50 & 6,50 & 2,00 \\
5 & Hijau & Ranita Purnama & 6,00 & 6,00 & - \\
6 & Hijau & Desi Kurniati, S.Pd & 4,50 & 6,00 & 1,50 \\
7 & Hijau & Sugiarti Puji Rahayu & 3,00 & 5,00 & 2,00 \\
8 & Kuning & Desmi Berty & 3,50 & 6,50 & 3,00 \\
9 & Kuning & Erivia Andriani & 6,00 & 6,50 & 0,50 \\
10 & Kuning & Fatma Yanis & 3,50 & 5,50 & 2,00 \\
11 & Kuning & Tiara Rahmadania & 4,00 & 5,00 & 1,00 \\
12 & Merah & Rita Susana & 3,00 & 5,00 & 2,00 \\
13 & Merah & Desti Yuliansary & 5,00 & 6,00 & 1,00 \\
14 & Merah & Ira Yunaine & 4,50 & 4,50 & - \\
15 & Merah & Serly Zursella & 6,00 & 6,00 & - \\
16 & Merah & Dinda Priscawati & 6,00 & 6,50 & 0,50 \\
\hline & & Rata-Rata & $\mathbf{4 , 4 4}$ & $\mathbf{6 , 0 0}$ & $\mathbf{1 , 5 6}$ \\
\hline
\end{tabular}

Dari tabel di atas, rata-rata nilai pre-test adalah 4,44 dan rata-rata nilai post-test sebesar 6,00. Nilai ini menunjukkan kenaikan tingkat pengetahuan mengenai akuntansi koperasi dan aplikasi akuntansis secara cloud accouting sebesar 1,56 poin.

Jika dianalisis nilai secara individual, pada saat pre-test terdapat empat orang peserta dengan nilai tertinggi 6,00. Namun, nilai post-test tertinggi tidak berasal dari empat orang 
nilai tertinggi saat pre-test. Nilai tertinggi post-test adalah 7,5 diperoleh oleh 2 orang peserta dengan kriteria unik, 1 orang peserta laki-laki dan 1 orang peserta perempuan dengan usia 61 tahun dari grup biru. Pada akhir kegiatan, grup biru menunjukkan kemajuan dan pertambahan pengetahuan yang paling signifikan dan memiliki dinamika kelompok yang sangat bagus.

Gambar 3 menunjukkan suasana saat pre-test dilakukan. Walaupun mereka adalah pengelola koperasi yang harus menyusun laporan keuangan, masih banyak yang belum dapat mengerti dan dapat menjawab dengan benar mengenai laporan keuangan yang mereka buat. Dari hasil diskusi, didapat informasi bahwa mereka lebih banyak mengandalkan pihak ketiga untuk menyusun laporan keuangan dan tidak melaksanakan siklus akuntansi secara benar dalam menyusun laporan keuangan.

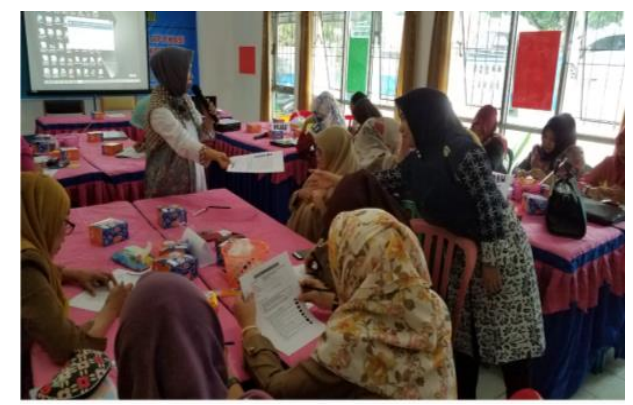

Gambar 3. Suasana Pre-test

Gambar 4 dan 5 merupakan Gambar kegiatan bagaimana peserta menyusun akunakun dari laporan keuangan koperasi dengan metode Galerry Walk. Setiap kelompok harus berdiskusi untuk menjawab pertanyaan fasilitator dengan menyusun materi pelatihan di dinding yang telah disediakan. Gambar 5 adalah contoh bagaimana hasil diskusi disajikan. Setiap kelompok memiliki kesempatan untuk memberikan saran dan komentar atas hasil pekerjaan kelompok lain. Kelompok yang diberi saran dapat memanfaatkan saran yang diberikan untuk memperbaiki hasil pekerjaan kelompok mereka.

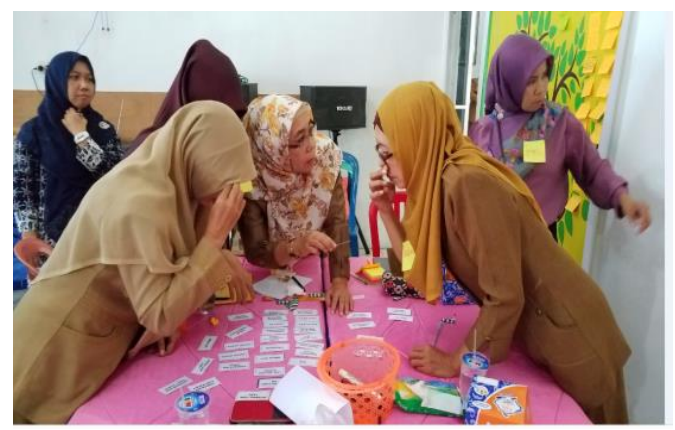

Gambar 4. Kelompok Kuning sedang mengelompokkan nama akun dengan Metode Galley Walk 


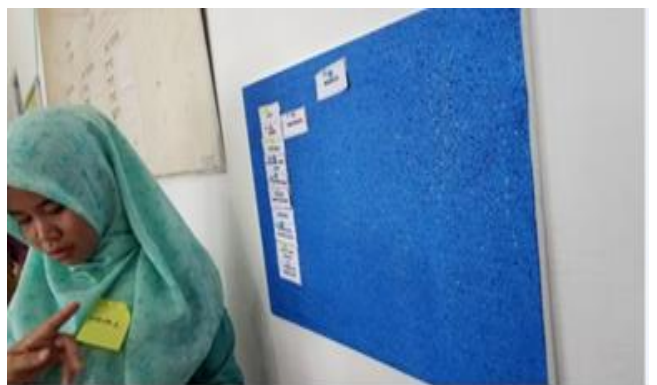

Gambar 5. Hasil Diskusi Kelompok Biru dalam mengelompokkan nama akun dengan Metode Gallery Walk

\section{Hasil Pelatihan Sleekr Accounting}

Pelatihan aplikasi sleekr Accounting dilaksanakan pada hari ke-2 pelatihan. Metode pelatihan yang diterapkan adalah metode campuran antara ceramah, diskusi, dan praktik. Untuk dapat menggunakan aplikasi ini, setiap user harus memiliki akun email, namun banyak peserta yang belum memiliki email, kalaupun memiliki email, mereka sudah lupa atas password akun mereka. Waktu yang cukup lama dihabiskan untuk memastikan semua peserta memiliki akun.

Gambar 6 merupakan salah satu email account yang akan digunakan dalam mendaftar aplikasi. Setelah e-mail account terverifikasi, setiap peserta harus mendaftar atau membuka account pada alamat http://accounting.sleekr.co dengan mendaftarkan nomor telepon dan nama email mereka. Verifikasi account sleekr accounting akan dilakukan melalui nomor telepon dan email.

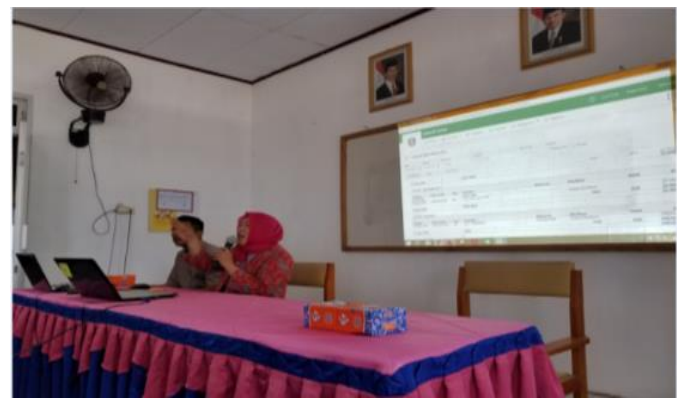

Gambar 6. Pemateri/Pelaksana Pengabdian menjelaskan bagaimana menyusun akun dengan menggunakan aplikasi sleekr. 


\section{Evaluasi kegiatan}

Tabel 4. Hasil Evaluasi Kegiatan

\begin{tabular}{|c|c|c|c|c|}
\hline Kegiatan & $\begin{array}{l}\text { Kriteria } \\
\text { Evaluasi }\end{array}$ & Indikator & Tolok Ukur & Hasil Evaluasi Kegiatan \\
\hline \multirow[t]{3}{*}{$\begin{array}{l}\text { Pelatihan dasar } \\
\text { akuntansi bagi } \\
\text { mitra }\end{array}$} & $\begin{array}{l}\text { Dapat } \\
\text { menyusun } \\
\text { Bagan akun } \\
\text { standar sesuai } \\
\text { karakteristik } \\
\text { kerja masing- } \\
\text { masing peserta }\end{array}$ & $\begin{array}{l}\text { Bagan akun } \\
\text { Pendapatan dan } \\
\text { Beban }\end{array}$ & $\begin{array}{l}\text { Pelatihan } \\
\text { dasar } \\
\text { akuntansi bagi } \\
\text { mitra }\end{array}$ & $\begin{array}{l}\text { Dapat menyusun Bagan akun } \\
\text { standar sesuai karakteristik } \\
\text { kerja masing-masing peserta }\end{array}$ \\
\hline & & $\begin{array}{l}\text { Bagan akun } \\
\text { Aset, Utang, dan } \\
\text { Modal }\end{array}$ & & $\begin{array}{l}\text { Total peserta yang hadir adalah } \\
\text { sebanyak } 16 \text { koperasi dari } 20 \\
\text { koperasi yang diundang atau } \\
80 \% \text { dari total yang diundang. } \\
\text { Dengan demikian, tolak ukur } \\
\text { jumlah peserta tercapai. }\end{array}$ \\
\hline & & Jumlah Peserta & Min $75 \%$ & $\begin{array}{l}\text { Jumlah peserta sebenarnya } \\
\text { lebih dari } 16 \text { orang, karena } \\
\text { beberapa koperasi membawa } \\
\text { lebih dari } 1 \text { orang peserta. } \\
\text { Pelaksana kegiatan tetap } \\
\text { memperbolehkan mereka } \\
\text { mengikuti kegiatan untuk } \\
\text { mendapatkan manfaat lebih } \\
\text { besar kepada masyarakat } \\
\text { terutama mitra. }\end{array}$ \\
\hline \multirow[t]{4}{*}{$\begin{array}{l}\text { Pelatihan } \\
\text { aplikasi Sleekr } \\
\text { Accounting. }\end{array}$} & $\begin{array}{l}\text { Sleekr } \\
\text { Accounting } \\
\text { telah berhasil } \\
\text { dan telah } \\
\text { disetting }\end{array}$ & $\begin{array}{l}\text { Akun Koperasi } \\
\text { telah berhasil } \\
\text { dibuat. }\end{array}$ & $\begin{array}{l}1 \text { akun } \\
\text { koperasi dari } \\
\text { mitra yang } \\
\text { bersangkutan }\end{array}$ & $\begin{array}{l}16 \text { akun pada aplikasi sleekr } \\
\text { telah berhasil dibuat, namun } \\
\text { masih menggunakan versi } \\
\text { freetrial selama } 14 \text { hari kerja. } \\
\text { Hal ini menunjukkan tolok } \\
\text { ukur kegiatan tercapai }\end{array}$ \\
\hline & $\begin{array}{l}\text { Dapat } \\
\text { menyusun set up } \\
\text { bagan akun pada } \\
\text { aplikasi Sleekr } \\
\text { Accounting }\end{array}$ & $\begin{array}{l}\text { Bagan akun } \\
\text { berhasil } \\
\text { dibentuk pada } \\
\text { aplikasi }\end{array}$ & $\begin{array}{l}\text { Bagan akun } \\
75 \% \text { tersusun }\end{array}$ & $\begin{array}{l}100 \% \text { bagan akun dari } 16 \\
\text { koperasi telah berhasil dibuat, } \\
\text { karena dengan aplikasi ini, } \\
\text { hanya melakukan perubahan } \\
\text { akun yang dibutuhkan saja, } \\
\text { akun lainnya dapat mengikuti } \\
\text { template yang telah disediakan. }\end{array}$ \\
\hline & $\begin{array}{l}\text { Dapat } \\
\text { menyusun buku } \\
\text { pembantu } \\
\text { piutang dan } \\
\text { utang pada } \\
\text { aplikasi Sleekr } \\
\text { Accounting }\end{array}$ & $\begin{array}{l}\text { Daftar Pinjaman } \\
\text { anggota dan } \\
\text { daftar simpanan } \\
\text { anggota }\end{array}$ & $\begin{array}{l}\text { Min } 25 \% \text { data } \\
\text { mitra masuk } \\
\text { ke dalam } \\
\text { aplikasi }\end{array}$ & $\begin{array}{l}\text { Untuk indikator ini tidak } \\
\text { tercapai karena tidak semua } \\
\text { data dapat dimasukkan karena } \\
\text { kendala waktu yang terbatas } \\
\text { dan jaringan internet yang } \\
\text { tidak memadai. Hanya ada } 1 \\
\text { mitra yaitu dari KPN SMIK } \\
\text { Kota Bengkulu telah berhasil } \\
\text { memasukkan data saldo awal } \\
\text { tahun ke dalam sistem. }\end{array}$ \\
\hline & & Jumlah Peserta & Min $75 \%$ & $\begin{array}{l}\text { Peserta hari kedua pelatihan } \\
100 \% \text { hadir dari total } 16 \text { orang. }\end{array}$ \\
\hline
\end{tabular}




\section{KESIMPULAN DAN SARAN}

\section{Kesimpulan}

Dari hasil kegiatan berlangsung dapat disimpulkan bahwa: masalah yang dihadapi oleh mitra berupa kurangnya pengetahuan di bidang ilmu akuntansi dan pemanfaatan aplikasi akuntansi dapat dijawab oleh pelatihan ini. Pelatihan ini menerapkan metode pelatihan aktif Gallery Walk. Dengan metode Gallery Walk, maka peserta didorong untuk saling belajar dari satu sama lain secara lebih aktif. Dari pelatihan selama 2 hari tersebut, maka mitra telah memiliki sumber daya manusia yang memiliki kompetensi yang lebih baik dari pada sebelumnya, terutama di bidang aplikasi akuntansi.

\section{Saran}

Dari pengamatan selama kegiatan, maka saran yang dapat diberikan adalah:

1. Untuk jenis pelatihan aplikasi, waktu pelatihan harus lebih lama.

2. Memastikan jaringan internet lancar dan kuat.

3. Memastikan peserta telah membawa seluruh dokumen koperasi saat pelatihan.

\section{DAFTAR PUSTAKA}

Hugos, M, and Hulitzky, 2011, Business in the Cloud: What Every Business Needs to KnowAbout Cloud Computing John Wiley \& Sons, Inc., Hoboken, New Jersey.

Narsa, Niluh Putu Dian Rosalina Handayan, 2017, SAK-ETAP Sebagai Solusi Overload Standar Akuntansi Bagi Usaha Mikro, Kecil, Menengah, Dan Koperasi, DOI: 10.24034/j25485024.y2017.v1.i1.1824 Available from: Https://Www.Researchgate. Net/Publication/317543652_SAK-ETAP_Sebagai_Solusi_Overload_Standar_Akun tansi_Bagi_Usaha_Mikro_Kecil_Menengah_Dan_Koperasi [accessed Mar 24 2018]. USAID-HELM, 2016, Fasilitator Perguruan Tinggi yang Efektif, USAID-Ristekdikti

Williams, Mark I, 2010, A Quick Start Guide to Cloud Computing: Moving Your Businessinto the Cloud, Coganpage, London. 